\title{
A decade of conservation effects assessment research by the USDA Agricultural Research Service: Progress overview and future outlook
}

M.D. Tomer, E.J. Sadler, R.E. Lizotte, R.B. Bryant, T.L. Potter, M.T. Moore, T.L. Veith, C. Baffaut, M.A. Locke, and M.R. Walbridge

\begin{abstract}
Ten years ago, the USDA Agricultural Research Service (ARS) began a series of watershed assessment studies as part of the Conservation Effects Assessment Project (CEAP). In this overview, a decade of research progress in 14 watersheds dominated by rain-fed croplands is reviewed to introduce a special section of this journal issue containing papers describing multiwatershed syntheses. The papers evaluate impacts of agricultural practices on soil quality, stream sediment sources, and the role of climate variability in watershed studies and conservation assessments at the watershed scale. The cross-watershed comparisons help enhance our understanding of emerging conservation technologies in terms of their readiness and suitability for wide-scale adoption. Research from ARS CEAP watershed assessments published during the past 10 years suggests encouraging (1) wider adoption of minimum disturbance technologies to reduce runoff risks associated with applying manure, nutrients, and agrichemicals; (2) adoption of winter cover crops; and (3) a renewed emphasis on riparian corridors to control loads of sediment, phosphorus $(\mathrm{P})$, and other contaminants originating from within (and near) stream channels. The management of agricultural watersheds requires that watershed-scale data can be interpreted and applied in management at the farm scale, and that farm-scale information, including financial and management constraints, can be used to clarify watershed management opportunities and challenges. Substantial research needs remain, including social engagement of agricultural communities, use of multiple conservation practices to account for environmental tradeoffs, improved models to simulate the dynamics of nutrient retention and movement in watersheds, and understanding ecosystem responses to changes in water quality. Moreover, a long-term commitment to understand land use trends, water quality dynamics, climate impacts, and the real effectiveness of precision conservation approaches for improving water quality will help secure agriculture's capacity to provide food, water, and other ecosystem services vital to society.
\end{abstract}

\section{Introduction: Ten Years of Conservation Effects Assessment Research}

The stability and safety of our nation's food supply depends on the availability and quality of our water supplies. Yet, in spite of many decades of conservation planning and implementation, impacts of agriculture on major water resources in the Gulf of Mexico (Turner et al.2008), Chesapeake Bay (Russell et al. 2008), the Great Lakes (Joose and Baker 2010), and many lakes and rivers in the United States are continuing, if not intensifying (Donner and Kucharik 2008).
This means that current efforts to conserve water and protect its quality on our agricultural landscapes have not been sufficient. Fortunately, scientific progress and social engagement have expanded our capacity to address water resource issues, encouraging renewed efforts. New technologies are now available to better assess water quantity and quality problems in watersheds, and our understanding of what is needed to implement these technologies is growing. Indeed, future progress on water quality improvement depends on the scientific assessment of water- sheds, and of conservation practices for their capacities to protect and treat surface and subsurface water. Ten years ago, little research had been aimed at determining how conservation practices improve water quality at the watershed scale. This special research section highlights progress made on this important area of research in the last decade by USDA's Agricultural Research Service (ARS).

In collaboration with the USDA Natural Resources Conservation Service (NRCS), the USDA ARS embarked on the Conservation Effects Assessment Project (CEAP) (Mausbach and Dedrich 2004; Richardson et al. 2008) in 2003. To mark CEAP's 10 year anniversary, in this overview we introduce a set of research papers comprising a special section of this journal issue and review research contributions from the ARS watershed studies under Croplands CEAP. The accompanying research papers follow a common theme, each providing an example of cross-location watershed research. Our underlying message is that conservation effects assessment research will become mature when our capacity to conduct multiwatershed research becomes well developed and research results are successfully used to plan and implement agricultural conservation systems that provide a clean

Mark D. Tomer is a research soil scientist with the USDA Agricultural Research Service (ARS) National Laboratory for Agriculture and the Environment in Ames, lowa. E. John Sadler is a research leader with the USDA ARS Cropping Systems and Water Quality Research Unit in Columbia, Missouri. Richard E. Lizotte is a research ecologist with the USDA ARS National Sedimentation Laboratory in Oxford, Mississippi. Ray B. Bryant is a research soil scientist with the USDA ARS Pasture System and Watershed Management Research Unit in University Park, Pennsylvania. Thomas $L$. Potter is a research chemist with the USDA ARS Southeast Watershed Research Unit in Tifton, Georgia. Matthew T. Moore is a research ecologist with the USDA ARS National Sedimentation Laboratory in Oxford, Mississippi. Tamie L. Veith is an agricultural engineer with the USDA ARS Pasture System and Watershed Management Research Unit in University Park, Pennsylvania. Claire Baffaut is a research hydrologist with the USDA ARS Cropping Systems and Water Quality Research Unit in Columbia, Missouri. Martin A. Locke is a research leader with the USDA ARS National Sedimentation Laboratory in Oxford, Mississippi. Mark R. Walbridge is a national program leader with Water Availability and Watershed Management. USDA ARS in Beltsville, Maryland. 
and reliable water supply. The papers in this special section are presented to provide examples that illustrate the value of multiwatershed research and indicate directions for future research that will help improve the management of agricultural watersheds.

This special section originates from a USDA ARS CEAP symposium held in July of 2012 at the Soil and Water Conservation Society's annual conference in Fort Worth, Texas. The symposium covered many research accomplishments; those that described new multiwatershed research are detailed within this special section's research papers. This article summarizes presentations given in the symposium, which reviewed previously published CEAP watershed research under the topics listed below (with lead authors in parentheses), and then suggests future directions for research:

- Implementation of nutrient reduction measures (R. Bryant)

- Factors impacting mitigation of pesticide runoff and leaching (T. Potter)

- Efficacy of edge-of-field conservation practices (M. Moore)

- Tools to improve practice placement efficacy (M. Tomer)

- Association between conservation practices and ecology (R. Lizotte)

\section{Summary of Progress}

Because of society's need to increase production and improve environmental outcomes from agriculture, new technologies are needed to better manage nutrients and agrichemicals, avoid and control their loss to the environment as pollutants, and sustain natural capacities to trap and treat pollutants at and beyond field edges. Research by USDA ARS scientists participating in CEAP has contributed towards the development of the new technologies that will contribute to these goals. The contributions are organized by the relative scale of application, beginning with in-field practices, followed by edgeof-field and riparian practices. Much of the research conducted under CEAP has focused on watershed assessment (as opposed to assessment of individual practices), and this progress overview concludes with watershed assessment technologies, touching on precision conservation, and assessments of riparian corridors and aquatic habitats.

Watershed assessment technologies are facilitated by monitoring data from multiple sources and contribute to the development of precision conservation approaches that agencies and stakeholders can use to improve agricultural production and the management of watersheds and riparian zones. Recognizing the importance of monitoring data, USDA ARS, as a public agency, is committed to data sharing as well as technology transfer. This commitment is evident in ARS's development of the Sustaining the Earth's Watersheds: Agricultural Research Data System (STEWARDS) as a publicly available resource for watershed analysis and assessment (Steiner et al. 2008; USDA ARS 2012). STEWARDS houses data being collected by 11 USDA ARS laboratories. It is also important to acknowledge that much of ARS's CEAP research has been conducted in collaboration with land grant institutions and other universities, which we acknowledge here and through citing key research papers authored by university colleagues and their students.

Finally, we emphasize that one critical aspect of watershed assessment and of gauging our understanding of watershed processes is simulation modeling. Watershed modeling has been a vital part of CEAP, and research in this area has made a significant contribution to the assessment of conservation effects, conducted using the Agricultural Policy Environmental Extender (APEX) (Williams et al. 2008), the Soil and Water Assessment Tool (SWAT) (Arnold et al. 1998) model, the Annual Agricultural Non-Point Simulation model (AnnAGNPS) (Bingner et al. 2009), and the Riparian Ecosystem Management Model (REMM) (Altier et al. 2002). Outcomes from APEX and SWAT were published in a series of regional assessment documents (USDA 2010) comprising a national assessment of conservation benefits. These contributions are highlighted in an accompanying feature article by Arnold et al. (2014 [this issue]).

\section{In-Field Conservation Practices.} Following a theme of multiwatershed research, we highlight two groups of conservation practices that have been researched at multiple locations: minimum disturbance application methods and cover crops. For both sets of practices, a broad geographic base of demonstrated water quality benefits can encourage wider adoption.

The term "Four R practices" refers to getting four things right when applying nutrients and agrichemicals to achieve high yields and avoid environmental impacts: right place, right time, right product, and right rate. This relatively simple concept can raise tactical issues that in many settings carry significant environmental tradeoffs. One important example involves the correct placement of nutrients, manure, and pesticides, which need to be incorporated below the soil surface to prevent losses in runoff and to the atmosphere, and to increase the efficiency of application in terms of crop uptake or weed/pest control. However, subsurface incorporation of these materials involves soil disturbance, essentially adding a tillage operation that can increase runoff risks on erosion-prone soils. To understand how to manage this tradeoff, research has been conducted on minimum disturbance application methods for a variety of products. Alternative technologies have been designed to incorporate manure with minimal soil disturbance within cropping systems that include minimum tillage, forage rotations, and/or winter cover crops (Maguire et al. 2011a). These technologies include aeration, shallow disk injection, and high pressure injection. Losses of manure-derived nutrients in runoff are decreased using these technologies, compared with broadcast. Ammonia $\left(\mathrm{NH}_{3}\right)$ volatilization, odor, and nutrient loss impacts of these technologies have been evaluated in the east-central United States (Brandt et al. 2011; Dell et al. 2012; Feyereisen et al. 2010; Johnson et al. 2011; Kleinman et al. 2009; Maguire et al. 2011b; Rotz et al. 2011; Verbree et al. 2010). In the Midwest, Kovar et al. (2011) showed how low disturbance manure application can be compatible with winter cover crops, reducing P losses in runoff.

Several herbicides perform best when incorporated, including atrazine $\left(\mathrm{C}_{8} \mathrm{H}_{14} \mathrm{ClN}_{5}\right)$ which is widely used for grass and broadleaf control in corn (Zea mays L.) production. Lerch et al. (2013) showed how minimum disturbance incorporation of atrazine using a low-disturbance harrow optimized the tradeoff between sediment and atrazine losses in runoff. Potter et al. $(2008,2011)$ showed how postapplication irrigation enhanced the delivery of herbicides to the soil surface without disturbing cover crop residue in conservation tillage systems, and helped to combat glyphosate $\left(\mathrm{C}_{3} \mathrm{H}_{8} \mathrm{NO}_{5} \mathrm{P}\right)$ resistant weeds. Their research, which focused on cotton (Gossypium hirsutum L.) and peanut (Arachis hypogaea L.) production in the southeastern United States, showed that incorporating herbicide with a 
light irrigation improved weed control and reduced the possibilities of runoff and injury to germinating crops. Reduced disturbance applications are also compatible with strip-tillage practices, as shown in the southeastern United States, where both surface and subsurface pathways can transport pesticides, especially where shallow lateral flows are important (Bosch et al. 2012). This research has become mature enough to encourage widespread adoption of minimum disturbance application/incorporation implements by producers. They can choose from a variety of minimum disturbance application methods, which is increasing adoption of this much needed conservation practice.

Cover crops are an important practice to improve soil health by reducing erosion, increasing carbon (C) cycling in soil, and controlling nutrient losses (Dabney et al. 2001). Studies across the United States have demonstrated the effectiveness of winter cover crops for reducing nutrient losses and/ or benefiting soil health (Brennan et al. 2010; Delgado et al. 2007; Kaspar et al. 2007; Rotz et al. 2006), encouraging USDA NRCS to provide incentives for cover crop establishment in both the Upper Mississippi River and Chesapeake Bay watersheds. To optimize the benefits of cover cropping, including scavenging of mineral nitrogen $(\mathrm{N})$ after grain harvest, seeding at the right time is necessary to ensure an adequate fall season for cover crop establishment and growth. A system to monitor and estimate cover crop establishment and fall growth was devised using remote sensing data (Hively et al. 2009), providing feedback to help producers improve the effectiveness of this practice. In the Northeast, where short growing seasons limit the window for effective fall seeding, simultaneous seeding of a red clover (Trifolium pretense L.) cover crop with corn planting can provide water quality benefits after corn harvest without affecting corn yield (Kleinman et al. 2005). In the Midwest, the window of time available to plant winter cover crops and provide for establishment and growth before onset of winter weather diminishes to the north, and recommendations for cover crop fall-seeding dates have been developed into southern Minnesota (Feyereisen et al. 2006). In spring, cover crops are killed with herbicides, and timing is important for establishment and $\mathrm{N}$ management of the succeeding grain crop. Research results have helped to inform management options in the
Midwest (Feyereisen et al. 2006; Kaspar et al. 2007; 2012) and Chesapeake Bay (Clark et al. 2007; McCarty et al. 2008; Rotz et al. 2006).

In research conducted in southern Florida designed to reduce agricultural impacts on water quality and enhance efforts to restore the Everglades ecosystem, Potter et al. (2007) and White et al. (2009) showed that use of summer crops on fields used for vegetable production during winter months reduced herbicide leaching to groundwater. Ground and surface waters are tightly linked in this area; thus the practice has broad benefits for protecting water quality and is recommended to local growers.

Edge-of-Field and Riparian Conservation Practices. Phosphorus-sorbing filters and denitrifying bioreactors provide ways to trap and treat nutrients in water at and below field edges. Research has been undertaken to evaluate the potential of industrial byproducts (e.g., water treatment residuals, flue-gas-desulfurization gypsum) to sorb $\mathrm{P}$ and limit its losses (Ippolito et al. 2011; Watts and Torbert 2009). Vegetative buffers can slow runoff velocity and trap sediment and particulate $\mathrm{P}$, but significant fractions of $\mathrm{P}$ in runoff are in dissolved form. Thus, there is a need to develop new practices that decrease concentrations of dissolved $\mathrm{P}$ in runoff. Buda et al. (2012) evaluated progress and challenges with the use of a variety of $\mathrm{P}$ filtering materials. Phosphorus sorption filters at field and stream edges need to be carefully engineered to realize performance potential, but sediment clogging and treatment of $\mathrm{P}$ loads during storm events are issues that will challenge efforts toward broad implementation. One example from the Chesapeake Bay's Delmarva Peninsula, where dissolved $\mathrm{P}$ can comprise $50 \%$ of total $\mathrm{P}$ concentration, investigated the use of a gypsum bed to immobilize dissolved $\mathrm{P}$ in drainage water as calcium phosphate $\left(\mathrm{Ca}_{3}\left[\mathrm{PO}_{4}\right]_{2}\right)$ (Bryant et al. 2012). During four years, removal efficiency averaged only $22 \%$, due to the limited flow capacity of the filter during large runoff events. In tile-drained landscapes in the Midwest, P losses to streams can occur via surface inlets installed in glacial depressions (Smith et al. 2008; Tomer et al. 2010); ongoing research is evaluating the use of $\mathrm{P}$ sorbing filters in these settings.

In the agriculturally intensive midsouthern United States, surface drainage containing pesticides and nutrients can potentially impair water quality. Vegetative filter practices such as constructed wetlands and vegetated drainage ditches have been examined as a possible remediation measure. In the Beasley Lake Watershed in Mississippi, a constructed wetland receiving simulated storm runoff resulted in $43 \%$ to $76 \%$ of the pesticides being sorbed to plant material (Moore et al. 2007, 2009). Herbicide concentrations were decreased $22 \%$ to $32 \%$ by the same wetland in a later study with a simulated runoff event (Locke et al. 2011). If wetland installation is not practical, vegetated drainage ditches can provide effective mitigation for pesticides and nutrients (Moore et al. 2001, 2010; Ahiablame et al. 2011). This research has considered effects of ditch maintenance on contaminant mitigation (Smith et al. 2006). California encourages farmers to use vegetated ditches for pesticide mitigation (practice standard 607A).

Denitrifying bioreactors (Blowes et al. 1994; Schipper et al. 2010) have been evaluated to reduce nitrate $\left(\mathrm{NO}_{3}\right)$ in tile drainage in the Midwest. There are a variety of configurations for bioreactors. Most designs will either naturally intercept tile flow in a buried trench or divert tile flow to a subsurface bed. The trench or bed is filled with a C substrate, typically woodchips. Research has shown that this technology is cost effective in comparison to other edge of field techniques for $\mathrm{NO}_{3}$ removal. An interim conservation practice standard (code 747) has been developed and cost share is now available for implementation.

Riparian buffers have been placed along many streams to attenuate the delivery of runoff, sediment, nutrients, and pesticides. Water quality benefits of buffers have been investigated in CEAP watersheds in Georgia, Oklahoma, and Puerto Rico. This research has been largely comprised of model simulations rather than field data (Cho et al. 2010; Moriasi et al. 2011; Williams et al. 2013). Potter et al. (2011) described use of REMM in evaluating buffer system efficacy in reducing pesticide runoff into streams and rivers in the southeastern United States. The importance of extreme large events in reducing the effectiveness of buffers on an average annual basis was also highlighted by the Potter et al. (2011) study and by Williams et al. (2013), who applied the APEX and REMM models in Puerto Rico's Hobos Bay. In addition, research has demonstrated that simulation models can be used to design buffers and evaluate their efficacy and placement (Cho 
et al. 2010; Potter et al. 2011). Finally, modeling results have also shown buffers can be important in controlling stream bank erosion (Moriasi et al. 2011), which has been shown to be extensive in most CEAP watersheds (Simon and Klimetz 2008).

Watershed Assessment. Watershed assessment is a multifaceted and multidisciplinary set of activities aimed at gathering information on the use and condition of soil and water resources within a drainage basin and how these resources are changing in response to management and climate. Much of the research conducted by USDA ARS under CEAP has contributed to watershed assessment, and the research papers within this special section help demonstrate the range of activities that comprise watershed assessment. Soil quality assessment conducted at the watershed scale can show how dominant management activities in a watershed are affecting soil health (Karlen et al. 2014). Repeated monitoring of soil quality over time can be used to identify changes in key soil properties (e.g., organic C, bulk density, and $\mathrm{pH}$ ) that impact soil productivity and hydrologic functioning (i.e., water infiltration, retention, and drainage). Garbrecht et al. (2014) evaluate the impacts of climate change and extreme events on the assessment of conservation practice effectiveness within watersheds. Examples of impact assessment at the watershed scale by way of computer simulation and analysis of field data are reviewed. These impacts include stream corridor stability, effectiveness of sediment control measures, how the benefits of conservation practices implemented upstream are propagated downstream, and implications for modeling rainfall-runoff and erosion processes. Kuhnle et al. (2014 [this issue]) summarize a multiwatershed assessment of sediment sources, in which data on radionuclides in stream sediments show the importance of channel and gully sources of sediment. This research is motivating a greater emphasis on management of riparian corridors for improving agricultural water quality, and new research efforts to better understand and predict the contribution of gullies to soil erosion in fields.

Watershed assessment research has revealed that, although a variety of conservation practices can improve water quality, conclusive verification using retrospective studies in large riverine watersheds is very difficult. Responses in stream (or river) water qual- ity to the implementation of conservation practices have been difficult to demonstrate for four reasons (Tomer and Locke 2011). First, the practices implemented may not adequately address the actual sources and pathways of contaminants that govern water quality. Second, sediment loads in streams are often dominantly sourced from the erosion of stream banks rather than erosion of field soils. Third, timing issues including historical legacies, shifts in climate, changes in land use (including but not limited to conservation practices), and lags in water quality responses combine to obscure the effects of conservation implementation. Fourth, when conservation practices are implemented to address one contaminant, tradeoffs among multiple contaminants that can be critical for managing water quality are often neglected. The good news is these four "disconnects" suggest strategies towards developing and improving watershed management technologies that can actually improve water quality with conservation practices. Combined use of new technologies including precision conservation (discussed below) and new farming methods that minimize soil disturbance could address the first and fourth of these disconnects, while improved approaches to riparian management should address the second in many settings. A commitment to watershed assessment and collection of longterm data on land use and water quality, at least for a set of watersheds representative of key landform regions (i.e., Environmental Protection Agency ecoregions or NRCS Major Land Resource Areas), could address the third in the longer term. This third disconnect requires greater efforts to understand how watersheds are changing in many ways. One of the less obvious challenges in watershed assessment is to monitor changes in land use as well as water quality over time. Changes in rotations and tillage systems are accompanied by changes in nutrient and pest management, and water quality responses will lag behind any changes in management (Meals et al. 2010). One example was given by Locke et al. (2008) who described agricultural changes in the Beasley Lake Watershed, which included drastic changes in amounts and types of agrichemical use over a 15-year period and a significant increase in conservation cover.

Assessment of riparian corridors help us to understand the most critical watershed vulnerabilities, because pollutants lost from riparian zones have the least distance to travel to impact water quality and aquatic ecosystems. Watershed assessment research under CEAP has shown that stream banks and beds are frequently important sources of the sediments transported in streams (Wilson et al. 2008; Simon and Klimetz 2008). Yan et al. (2010) evaluated channel movement and historical sedimentation in the Iowa River's South Fork Watershed, highlighting issues of channel condition that arise from the combined impact of channel straightening and sediment accretion. Kuhnle et al. (2014 [this issue]) update this research in a multiwatershed assessment. Conservation Effects Assessment Project research in several locations has also indicated that streambeds and riparian pastures can be a disproportionate source of both $\mathrm{P}$ and bacteria in streams (Ghebremichael et al. 2007; Harmel et al. 2010; James et al. 2007; Tomer et al. 2010).

One often overlooked aspect of watershed assessment concerns the statistical treatment of data collected from stream gaging and water quality sampling, and statistical assessment of simulation model performance. Whether originating from direct measurements or model simulations, all data clearly have errors and uncertainty associated with them. Contributions have been made under CEAP to help scientists and stakeholders cope with data uncertainty. Sources of measurement errors in water quality studies were distinguished and the relative magnitude of those errors quantified (Harmel et al. 2006). In paired watershed studies, assessment of pretreatment data can indicate a priori the magnitude of change in a response variable that will be required to detect a treatment effect with statistical confidence (King et al. 2008). The SWAT model parameter sensitivity and uncertainty comparisons in five USDA ARS watersheds that span the United States have provided insights for model users (Veith et al.2010); continuing research in this area addresses uncertainties in model structures and in representation of the natural system as a whole. Guidelines for model validation and assessment (Moriasi et al. 2007) have helped scientists and engineers apply and evaluate models more consistently across a variety of watersheds. These guidelines do not address all model validation issues however. Wider use of indices and statistical characterization of hydrologic regime (i.e., flashiness or seasonality) in assessing model 
simulations of daily stream discharge was recently suggested (Tomer et al. 2013a).

Precision Conservation. Watershed-scale information can help identify and prioritize key vulnerabilities, indicate the types of conservation practices that can address those vulnerabilities, and identify where those conservation practices should be placed to improve water quality. Known as precision conservation (Delgado and Berry 2008), this concept has inherent appeal because it infers the efficient use of resources (i.e., incentive funds and acreage set aside) to improve water quality using conservation practices. At the watershed scale, advances in computing speed and geospatial evaluation can now support multiobjective optimization of conservation practices for cost-effective water quality improvement (Ghebremichael et al. 2010; Gitau et al. 2006; Veith et al. 2004). However, the ability to actually implement precision conservation strategies requires the translation of detailed watershed-scale data to the farm scale, and vice versa (Ghebremichael et al. 2013). Research conducted by ARS under CEAP has illustrated the importance and benefits of translating information between farm and watershed scales by a variety of approaches, to which the following four examples of watershed research testify.

Claypan soils in Missouri presents challenges for managing agricultural runoff and the transport of sediment and pesticides (Lerch et al.2008).A 35 ha (87 ac) field in the Goodwater Creek Experimental Watershed (GCEW) was partitioned into 35 management zones based on soil type and depth to claypan, and environmental losses from each zone were evaluated using APEX (Mudgal et al. 2012). Data on slope, claypan depth, and hydraulic conductivity in each management zone were combined into two indices, which were then used to score the management zones for relative susceptibility to losses of runoff, atrazine, and sediment. The index values were correlated with validated APEX results and then applied across the GCEW to prioritize locations where conservation cover and practices to control runoff and atrazine losses should be implemented. This study is one example of how detailed field-scale data and modeling can be extended to provide information for water quality protection at the watershed scale.

On Maryland's Eastern Shore, cover crops are being encouraged to limit nutri- ent losses to the Chesapeake Bay (McCarty et al. 2008). Remote sensing data collected during fall were used in combination with field sampling to map cover crop biomass across several watersheds. Variations in biomass were explained by planting date, prior crop, planting method, and cover crop species (Hively et al. 2009). Because the cover crop biomass determines nutrient uptake, the results could be used to evaluate the cost effectiveness of incentive programs that encourage cover crop establishment and provide information to local agencies able to consult with local farmers participating in the incentive program to help them improve the management of cover crops. In this case, watershed-scale data provided information to improve management on individual fields through extension and on-farm consultation.

In Illinois, detailed topographic data obtained by a light detection and ranging (LiDAR) survey were used to identify locations where appropriately sized nutrient removal wetlands could be installed without inundating up-gradient croplands or infrastructure (Tomer et al. 2013b). The AnnAGNPS model was used to estimate inflow volumes and $\mathrm{N}$ loads to each wetland, from which denitrification was estimated using statistical relationships established from wetland studies in Iowa. The wetlands were ranked according to anticipated $\mathrm{N}$ removal on an annual, unit-area basis, which varied widely based on wetland-to-contributing area ratios and upslope land use (Tomer et al. 2013b). This watershed-scale information could inform nutrient trading schemes and be used to identify specific farms where incentives offered for wetland establishment should provide the greatest nutrient removal.

In the northeastern United States, Lake Champlain provides an important drinking water supply and a resource for fishing and tourism, but has been impacted by eutrophication. A reduction of $52 \%$ in $\mathrm{P}$ loading to the lake is being sought; to achieve this goal, local dairy farms will need to implement nutrient control practices (Ghebremichael et al. 2013). The SWAT model (Arnold et al. 1998) was applied to a subbasin of the lake to evaluate the effectiveness of conservation scenarios including cover crops, riparian buffers, and contour tillage. A scenario including all three practices provided an encouraging $48 \% \mathrm{P}$ load reduction, but evaluation at the farm level showed these measures to be costly. Farm level modeling identified pre- cision feeding (Ghebremichael et al. 2007) and forage management practices to provide an effective approach to $\mathrm{P}$ reduction that improved farm profitability, especially in combination with the adoption of no-tillage systems. The economic benefit from these practices provides the farmer with an incentive to implement buffers and cover crops toward improving lake water quality. In this instance (Ghebremichael et al. 2013), modeling results at watershed and farm scales were combined to encourage farmer engagement through the recognition that, within their operations, economic and environmental goals can be compatible.

In each of these four examples, detailed watershed-scale data provided information relevant to conservation and nutrient/pesticide management at the farm level. The specific goals, modeling approaches, and practices considered all varied, but information useful to farmers and/or local staff working directly with farmers was provided based on watershed-scale data. The ability to translate information from the watershed to the farm scale provided direct help towards stakeholder engagement in all four of these studies and is an important lesson for future agricultural watershed management.

Aquatic Ecology. As their primary goal, agricultural conservation practices implemented in most watersheds have focused on mitigating loadings of agricultural pollutants to surface waters, including sediment, nutrients (i.e., $\mathrm{N}$ and $\mathrm{P}$ ), and fractional pesticide losses. This focus on water quality constituents is underpinned by goals to mitigate impacts on aquatic biota, including decreases in nuisance algae and increases in aquatic invertebrates and fishery resources. Invertebrates, fish, and algae are the three components of aquatic ecosystems most recognized by the general public. Although there is an abundance of literature on the effects of conservation practices on agricultural pollutants (Dinnes et al. 2002; Hansen et al. 2007; Osmond et al. 2012), and we can simulate these benefits (Arabi et al. 2008), much less has been published on measured ecological responses (Locke et al.2008; Maret et al.2008; Bosch et al. 2009; Smiley et al. 2009). This implies a working assumption that if agricultural pollutants are reduced aquatic ecology and biodiversity will improve. However, ecological responses to conservation are indirect and often very complex (Maret et al. 2008). Within CEAP, for example, research in the 
Beasley Lake Watershed showed significant reductions in total suspended sediments, leading to increases in light penetration allowing for increased algal biomass over time (Knight et al. 2008; Lizotte et al. 2012). In turn, the increase in primary producer biomass was followed by an increase in fish biomass for two sport fishes, largemouth bass (Micropterus salmoides) and bluegill sunfish (Lepomis macrochirus) (Locke et al. 2008). In contrast, despite widespread implementation of conservation practices in two Midwestern watersheds, Cedar Creek and Upper Big Walnut Creek, research showed improvements in physical and chemical water quality had only a minimal influence on stream fish communities (Smiley et al. 2009, 2012). Further research by Smiley et al. (2011) indicated that along with improved water quality, improvements in physical habitat would be needed to enhance fish biodiversity in agricultural stream ecosystems. A third example of the ecological complexity inherent within aquatic systems evaluated low dissolved oxygen $\left(\mathrm{O}_{2}\right)$ within the Little River CEAP Watershed in Georgia (Carey et al. 2007). A concern for possible impacts of agricultural nutrients led to research aimed at determining if the source of low dissolved $\mathrm{O}_{2}$ was natural or agricultural in origin. Interestingly, results showed that the primary source of low dissolved $\mathrm{O}_{2}$ did not result from agricultural nutrient stimulation of algal blooms (Carey et al. 2007), but from natural influxes of dissolved and particulate $\mathrm{C}$ and consequent increases in microbial $\mathrm{O}_{2}$ demand in stream sediments (Todd et al. 2009). Although these studies provide valuable insights into how agricultural conservation practices may improve and rehabilitate aquatic ecosystems in agricultural watersheds, there remains a long-term need for watershed assessments to include the assessment of ecosystem services in aquatic, riparian, and upland systems (Brauman et al. 2007).

\section{Future Directions}

Water quality improvements in agricultural watersheds, precision conservation technologies, and watershed simulation models will need to be combined to engage stakeholders to implement and maintain conservation measures that are environmentally effective and cost efficient. There are technology development and social engagement obstacles that we need to overcome in order for effective measures take place. Progress is being made in technical/research arenas, and social barriers are now better understood (Osmond et al. 2012). A watershed approach needs to be observed to allow scientists, conservationists, and landowners to interact while developing and applying technologies and tools that can sustain agricultural watersheds, as well as other ecosystem services. Research by ARS can help meet the challenges that will be encountered, including assessments of field and edge-of-field practices, and the development of enhanced technologies for precision conservation planning and watershed simulation. These obstacles would be best addressed in collaborative networks, such as ARS's recently initiated Long-Term Agro-ecosystem Research (LTAR) network (Bartuska et al. 2012). The challenges that agricultural watershed research face include the following:

- Improving simulation models and their demonstrated capacity to simulate nutrient loads $(\mathrm{N}$ and $\mathrm{P})$ in streams and rivers, as well as pesticide transport.

- Developing watershed planning tools to optimize the efficiency of conservation practices with linkage to models to evaluate different practice-placement and design scenarios.

- Undertaking a wider exploration of the linkages between watershed-scale and farm-scale data and how to best apply these linkages in watershed management.

- Improving our understanding of how one conservation practice can improve or diminish the relative performance of another practice, and thereby develop a capability to combine different conservation practices that can compensate for environmental and ecosystem services tradeoffs that are an inherent aspect of agri-environmental management.

- Establishing watershed observatories and networks for soil and water quality monitoring to help understand long term changes in soil and water resources and ecosystem services, and impacts of changes in conservation, agricultural management, and climate.

- Determining if and how conservation practices can improve the resilience of agricultural soils and watersheds under wide ranging weather conditions including drought and extreme runoff events.

- In concert with social scientists, finding the balance that recognizes both the critical importance of resource protection to future generations, and the entrepre- neurial independence of individual farm operations, while demonstrating successful watershed outcomes.

By taking full advantage of lessons learned through stakeholder engagement, and by a continued effort to understand how watershed resources respond to ongoing changes in land use, climate, and human needs, we can ensure the capacities of our agricultural landscapes for providing equally critical food and water supplies are sustained into the future.

\section{References}

Ahiablame, L.M., I. Chaubey, D.R. Smith, and B.A. Engel. 2011. Effect of tile effluent on nutrient concentration and retention efficiency in agricultural drainage ditches. Agricultural Water Management 98(8):1271-1279.

Altier, L.S., R.R. Lowrance, R.G. Williams, S.P. Inamdar, D.D. Bosch, J.M. Sheridan, R. K. Hubbard, and D.L. Thomas. 2002. Riparian ecosystem management model: Simulator for ecological processes in riparian zones. Washington DC: US Department of Agriculture, Agricultural Research Service Conservation Research Report 46.

Arabi, M., J.R. Frankenberger, B.A. Engel, and J.G. Arnold. 2008. Representation of agricultural conservation practices with SWAT. Hydrological Processes 22:3042-3055

Arnold, J.G., R. Srinivasan, R.S. Muttiah, and J.R. Williams. 1998. Large area hydrologic modeling and assessment: Part 1. Model development. Journal American Water Resources Association 34(1):73-89.

Arnold, J.G., and others. 2014. Impact of the ARS Benchmark Watershed Project on the CEAP National Cropland Assessment and Conservation Policy. Journal of Soil and Water Conservation this issue

Bartuska, A., M.R. Walbridge, and S.R. Shafer. 2012. Long-term agro-ecosystem research (LTAR) and the global challenges to food and agriculture. Water Resources Impact 14(5):8-10.

Bingner, R.L., F.D. Theurer, and Y. Yuan. 2009. AnnAGNPS Technical Processes. Washington DC: United States Department of Agriculture Agricultural Research Service http://www.ars.usda.gov/Research/ docs.htm?docid=5199

Blowes, D.W., W.D. Robertson, C.J. Ptacek, and C. Merkley. 1994. Removal of agricultural nitrate from tile-drainage effluent water using in-line bioreactors. Journal of Contaminant Hydrology 15:207-221.

Bosch, D.D., C.C. Truman, T.L. Potter, L.T. West, T.C. Strickland, and R.K Hubbard. 2012. Tillage and slope position impact on field-scale hydrologic processes in the South Atlantic Coastal Plain. Agricultural Water Management 111:40-52.

Bosch, I., J.C. Makarwicz, T.W. Lewis, E.A. Bonk, M. Finiguerra, and B. Groveman. 2009. Management of agricultural practices results in declines of filamentous 
algae in the lake littoral. Journal of Great Lakes Research 35:90-98.

Brandt, R.C., H.A. Elliott, M.A.A. Adviento-Borbe, E.F. Wheeler, P.J.A. Kleinman, and D.B. Beegle. 2011. Influence of manure application method on odor emissions. Journal of Environmental Quality 40:431-437.

Brauman, K.A., G.C. Daily, T.K. Duarte, and H.A Mooney. 2007. The nature and value of ecosystem services: An overview highlighting hydrologic services. Annual Review of Environmental Resources 32:67-98.

Brennan, E.B., N.S. Boyd, R.F. Smith, and P. Foster. 2010. Comparison of rye and legume-rye cover crop mixtures for vegetable production in California. Agronomy Journal 103(2):449-463.

Bryant, R.B., A.R. Buda, P.J.A. Kleinman, C.D. Church, L.S. Saporito, G.J. Folmar, S. Bose, and A.L. Allen. 2012. Using flue gas desulfurization gypsum to remove dissolved phosphorus from agricultural drainage waters. Journal of Environmental Quality 41(3):664-671.

Buda, A.R., G.F. Koopmans, R.B. Bryant, and W.J. Chardon. 2012. Emerging technologies for removing nonpoint phosphorus from surface water and groundwater: Introduction. Journal of Environmental Quality 41:621-627.

Carey, R., G. Vellidis, R. Lowrance, and C. Pringle. 2007. Do nutrients limit algal periphyton in small blackwater Coastal Plain streams? Journal of the American Water Resources Association 43(5):1183-1193.

Cho, J., G. Vellidis, D.D. Bosch, R. Lowrance, and T. Strickland. 2010. Water quality effects of simulated conservation practice scenarios in the Little River Experimental Watershed. Journal of Soil and Water Conservation 65(6):463-473, doi:10.2489/jswc.65.6.46.

Clark, A.J., J.J. Meisinger, A.M. Decker, and F.R. Mulford. 2007. Effects of a grass-selective herbicide in a vetch-rye cover crop system on nitrogen management. Agronomy Journal 99(1):36-42.

Dabney, S.M., J.A. Delgado, and D.W. Reeves. 2001. Using winter cover crops to improve soil and water quality. Communications in Soil Science and Plant Analysis 32:1221-1250

Delgado, J.A., and J.K. Berry. 2008. Advances in Precision Conservation. Advances in Agronomy 98:1-44.

Delgado. J.A., M.A. Dillon, R.T. Sparks, and S.Y.C. Essah. 2007. A decade of advances in cover crops. Journal of Soil and Water Conservation 62(5):110A-117A.

Dell, C.J., P.J.A. Kleinman, J.P. Schmidt and D.B. Beegle 2012. Low disturbance manure incorporation effects on ammonia and nitrate loss. Journal of Environmental Quality 41: 928-937.

Dinnes, D.L., D.L. Karlen, D.B. Jaynes, T.C. Kaspar, J.L. Hatfield, T.S. Colvin, and C.A. Cambardella. 2002 Nitrogen management strategies to reduce nitrate leaching in tile-drained Midwestern soils. Agronomy Journal 94:153-171.
Donner, S.D., and C.J. Kucharik. 2008. Corn-based ethanol production compromises goal of reducing nitrogen export by the Mississippi River. Proceedings National Academy of Science 105(11):4513-4518.

Duriancik, L.F., D. Bucks, J.P. Dobrowolski, T. Drewes, S.D. Eckles,L. Jolley, R.L. Kellogg, D. Lund, J.R. Makuch, M.P. O'Neill, C.A. Rewa, M.R. Walbridge, R. Parry, and M.A. Weltz. 2008. The first five years of the Conservation Effects Assessment Project. Journal of Soil and Water Conservation 63(6):185A-197A doi:10.2489/jswc.63.6.185A

Feyereisen, G.W., P.J.A. Kleinman, G.J. Folmar, L.S Saporito, C.D Church, T.R. Way, and A.L Allen. 2010. Effect of direct incorporation of poultry litter on phosphorus leaching from Coastal Plain soils. Journal of Soil and Water Conservation 65:243-251, doi:10.2489/ jswc.65.4.243.

Feyereisen, G.W., B.N. Wilson, G.R. Sands, J.S. Strock, and P.M. Porter. 2006. Potential for a rye cover crop to reduce nitrate loss in southwestern Minnesota. Agronomy Journal 98(6):1416-1426.

Garbrecht J.D., M. Nearing, F.D. Shields, M.D. Tomer, E.J Sadler, J. Bonta, and C. Baffaut. 2014. Impact of weather and climate scenarios on conservation assessment outcomes. Journal of Soil and Water Conservation 69(5):383-401

Ghebremichael, L.T., P.E. Cerosaletti, T.L Veith, C.A Rots, J.M. Hamlett, and W.J. Gburek. 2007. Economic and phosphorus-related effects of precision feeding and forage management at a farm scale. Journal of Dairy Science 90:3700-3715.

Ghebremichael, L.T., T.L. Veith, and J.M. Hamlett. 2013. Integrated watershed- and farm-scale modeling framework for targeting critical source areas while maintaining farm economic viability. Journal of Environmental Management 114:381-394.

Gitau, M.W., T.L. Veith, W.J. Gburek, and A.R. Jarret. 2006. Watershed level Best Management Practice selection and placement in the Town Brook Watershed, New York. Journal American Water Resources Association 42(6):1565-1581.

Hansen, L. 2007. Conservation Reserve Program: Environmental benefits update. Agricultural \& Resource Economics Review 36(2):267-280.

Harmel, R.D., R.J. Cooper, R.M. Slade, R.L. Haney, and J.G. Arnold. 2006. Cumulative uncertainty in measured streamflow and water quality data for small watersheds. Transactions American Society of Agricultural Biological Engineers 49(3):689-701.

Harmel, R.D., R. Karthikeyan, T. Gentry, and R. Srinivasan. 2010. Effects of agricultural management, land use, and watershed scale on E. coli concentrations in runoff and streamflow. Transactions American Society of Agricultural Biological Engineers 53(6):1833-1841

Hively, W.D., M. Lang, G.W. McCarty, J. Keppler,A. Dadeghi, and L.L. McConnell. 2009. Using satellite remote sensing to estimate winter cover crop nutrient uptake efficiency. Journal of Soil and Water Conservation 64(5):303-313, doi:10.2489/jswc.64.5.303.

Ippolito, J.A., K.A. Barbarick, and H.A. Elliot. 2011. Drinking Water Treatment Residuals: A Review of Recent Uses. Journal of Environmental Quality 40(1):1-12.

James, E., P.J.A. Kleinman, T.L. Veith, R.C. Stedman, and A.N. Sharpley. 2007. Phosphorus contributions from pastured dairy cattle to streams of the Cannonsville Watershed, New York. Journal of Soil and Water Conservation 62(1):40-47.

Johnson, K.N., P.J.A. Kleinman, D.B. Beegle, and H.A Elliott. 2011. Effect of dairy manure slurry application in a no-till system on phosphorus runoff. Nutrient Cycling in Agroecosystems 90:201-212.

Joose, P.J., and D.B. Baker. 2010. Context for re-evaluating agricultural source phosphorus loadings to the Great Lakes. Canadian Journal of Soil Science 91:317-327.

Karlen, D.L., D.E. Stott, C.A. Cambardella, R.J. Kremer, K.W. King, and G.W. McCarty. 2014. Midwest land management effects on near-surface soil quality indicators. Journal of Soil and Water Conservation 69(5): 374-382.

Kaspar, T.C., D.B. Jaynes, T.B. Parkin, and T.B. Moorman. 2007. Rye cover crop and gamagrass strip effects on $\mathrm{NO}_{3}$ concentration and load in tile drainage. Journal of Environmental Quality 36:1503-1511.

Kaspar, T.C., D.B. Jaynes, T.B. Parkin, and T.B. Moorman, and J.W. Singer. 2012. Effectiveness of oat and rye cover crops in reducing nitrate losses in drainage water. Agricultural Water Management 110:25-33.

King, K.W., P.C. Smiley, B.J. Baker, and N.R. Fausey. 2008. Validation of paired watersheds for assessing conservation practices in the Upper Big Walnut Creek watershed, Ohio. Journal of Soil and Water Conservation 63(6):380-395, doi:10.2489/jswc.63.6.380.

Kleinman, P.J.A., P. Salon, A.N. Sharpley, and L.S Saporito. 2005. Effect of cover crops established at time of corn planting on phosphorus runoff from soils before and after dairy manure application. Journal of Soil and Water Conservation 60(6):311-22.

Kleinman, P.J.A.,A.N. Sharpley, L.S. Saporito, A.R. Buda and R.B. Bryant. 2009. Application of manure to no-till soils: Phosphorus losses by sub-surface and surface pathways. Nutrient Cycling in Agroecosystems 84: 215-227.

Knight, S.S., R.F. Cullum, C.M. Cooper, and R.E. Lizotte. 2008. Effects of suspended sediments on the chlorophyll-phosphorus relationship in oxbow lakes. International Journal of Ecology and Environmental Sciences 34(1):1-6.

Kovar, J.L., T.B. Moorman, J.W. Singer, C.A Cambardella, and M.D. Tomer. 2011. Swine manure injection with low-disturbance applicator and cover crops reduce phosphorus losses. Journal of Environmental Quality 40(2):329-336

Lerch, R.N., E.J. Sadler, N.R. Kitchen, K.A. Dudduth, R.J. Kremer, D.B. Myers, C. Baffaut, S.H. Anderson, and 
C.-H. Lin. 2008. Overview of the Mark Twain Lake/Salt River basin Conservation Effects Assessment Project. Journal Soil Water Conservation 63(6):345-359.

Lerch, R.N., C.M. Harbourt, R.R. Broz, and T.J. Thevary. 2013. Atrazine incorporation and soil erosion: Balancing competing water quality concerns for claypan soils. Transactions American Society of Agricultural Biological Engineers 56(6):1305-1316.

Lizotte, R., S. Knight, M. Locke, W. Steinriede, S. Testa, and C. Bryant. 2012. Water quality monitoring of an agricultural watershed lake: the effectiveness of agricultural best management practices. In Design and Nature IV: Comparing Design In Nature with Science and Engineering, eds. S. Hernandez and C. Brebbia, p. 283-294. United Kingdom: WIT transactions in Ecology and the Environment Series, volume 160.

Locke, M.A., S.S. Knight, S. Smith Jr., R.F. Cullum, R.M. Zablotowicz, Y. Yuan, and R.L. Bingner. 2008. Environmental quality research in the Beasley Lake watershed, 1995 to 2007: Succession from conventional to conservation practices. Journal of Soil and Water Conservation 63(6):430-442, doi:10.2489/ jswc.63.6.430.

Locke, M.A., M.A. Weaver, R.M. Zablotowicz, R.W. Steinriede, C.T. Bryson, and R.F. Cullum. 2011. Constructed wetlands as a component of the agricultural landscape: Mitigation of herbicides in simulated runoff from upland drainage areas. Chemosphere 83:1532-1538.

Maguire, R.O., P.J.A. Kleinman, and D.B. Beegle. 2011b. Novel manure management technologies in no-till and forage systems: Introduction to the special series. Journal of Environmental Quality 40:287-291.

Maguire, R.O., P.J.A. Kleinman, C.J. Dell, D.B. Beegle, R.C. Brandt, J.M. McGrath, and Q.M. Ketterings. 2011a. Manure application technology in reduced tillage and forage systems: A review. Journal of Environmental Quality 40:292-301.

Maret, T.R., D.E. MacCoy, and D.M. Carlisle. 2008. Longterm water quality and biological responses to multiple best management practices in Rock Creek, Idaho. Journal of the American Water Resources Association 44(5):1248-1269.

Mausbach, M.J., and A.R. Dedrick. 2004. The length we go: Measuring environmental benefits of conservation practices. Journal of Soil and Water Conservation 59:96A-103A.

McCarty, G.W., L.L. McConnell, C.J. Hapeman, A. Sadeghi, C. Graff, W.D. Hively, M.W. Lang, T.R. Fisher, T. Jordan, C.P. Rice, E.E. Codling, D. Whitall, A. Lynn, J. Keppler, and M.L. Fogel. 2008. Water quality and conservation practice effects in the Choptank River watershed. Journal of Soil and Water Conservation 63(6):461-474, doi:10.2489/ jswc.63.6.461.

Meals, D.W., S.A. Dressing, and T.E. Davenport. 2010. Lag time in water quality response to best management practices: A review. Journal of Environmental Quality 39(1):85-96.

Moore, M.T., E.R. Bennett, C.M. Cooper, S. Smith, Jr., F.D. Shields, Jr., C.D. Milam, and J.L. Farris. 2001. Transport and fate of atrazine and lambda-cyhalothrin in an agricultural drainage ditch in the Mississippi Delta, USA. Agriculture, Ecosystems and Environment 87:309-314

Moore, M.T., C.M. Cooper, S. Smith, Jr., R.F. Cullum, S.S. Knight, M.A. Locke, and E.R. Bennett. 2007. Diazinon mitigation in constructed wetlands: Influence of vegetation. Water, Air and Soil Pollution 184:313-321.

Moore, M.T., C.M. Cooper, S. Smith, Jr., R.F. Cullum, S.S. Knight, M.A. Locke, and E.R. Bennett. 2009. Mitigation of two pyrethroid insecticides in a Mississippi Delta constructed wetland. Environmental Pollution 157:250-256.

Moore, M.T., R. Kröger, M.A. Locke, R.F. Cullum, R.W. Steinriede, Jr., S. Testa III, R.E. Lizotte, Jr., C.T. Bryant, and C.M. Cooper. 2010. Nutrient mitigation capacity in Mississippi Delta, USA drainage ditches. Environmental Pollution 158:175-184.

Moriasi, D.N., J.G. Arnold, M.W. Van Liew, R.L. Bingner, R.D. Harmel, and T.L. Veith. 2007. Model evaluation guidelines for systematic quantification of accuracy in watershed simulations. Transactions American Society of Agricultural Biological Engineers 50(3):885-900.

Moriasi, D.N., J.L. Steiner, and J.G. Arnold. 2011. Sediment measurement and transport modeling: Impact of riparian and filter strip buffer. Journal of Environmental Quality 39:1-8.

Mudgal, A., C. Baffaut, S. H. Anderson, E. J. Sadler, N. R. Kitchen, and R. N. Lerch. 2012. Using the Agricultural Policy/Environmental eXtender to develop and validate physically based indices for the delineation of critical management areas. Journal of Soil and Water Conservation 67(4):282-297, doi:10.2489/ jswc.67.4.284.

Osmond, D.L., D.W. Meals, A.N. Sharpley, M.L. McFarland, and D.E. Line. 2012. Conservation practice implementation and maintenance: National Institute of Food and Agriculture - Conservation Effects Assessment Project. In How to Build Better Agricultural Conservation Programs to Protect Water Quality, eds. D. Osmond, D. Meals, D. Hoag, and M. Arabi, p.36-57. Ankeny, IA: Soil and Water Conservation Society.

Potter, T.L., D.D. Bosch, H. Joo, B. Schaffer, and R. Muñoz-Carpena, R. 2007. Summer cover crops reduce atrazine leaching to shallow groundwater in Southern Florida. Journal of Environmental Quality 36(5): 1301-1309.

Potter, T.L., C.C. Truman, T.C. Strickland, D.D. Bosch, and T.M. Webster. 2008. Herbicide incorporation by irrigation and tillage impact on runoff loss. Journal of Environmental Quality 37(3): 839-847.
Potter, T.L., C.C. Truman, T.M. Webster, T.C. Strickland, and D.D. Bosch. 2011. Cover-Crop Residue Management, and Irrigation Incorporation Impact on Fomesafen Runoff. Journal of Agricultural and Food Chemistry 59(14): 7910-7915

Potter, T.L., R.R. Lowrance, R. Williams, and D.D. Bosch. 2011. Estimating Pesticide Retention Efficacy for Edge-of-Field Buffers Using the Riparian Ecosystem Management Model (REMM) in a Southeastern Plains Landscape. In Pesticide Mitigation Strategies for Surface Water Quality, eds. K. Goh, B. Bret, J. Gan, T.L. Potter, pp. 259-271. Washington, DC: American Chemical Society Symposium Series No. 1075.

Richardson, C.W., D.A. Bucks, and E.J. Sadler. 2008. The Conservation Effects Assessment Project benchmark watersheds: Synthesis of preliminary findings. Journal of Soil and Water Conservation 63(6):590-604, doi:10.2489/jswc.63.6.590.

Rotz, C.A., P.J.A. Kleinman, C.J. Dell, T.L. Veith and D.B. Beegle. 2011. Environmental and economic comparisons of manure application methods in farming systems. Journal of Environmental Quality 40: 438-448.

Rotz, C.A., J. Oenema, and H. van Keulen. 2006. Whole farm management to reduce nutrient losses from dairy farms: A simulation study. Applied Engineering in Agriculture 22(5):773-84.

Russell, M.J., D.E. Weller, T.E. Jordan, K.J. Sigwart, and K.J. Sullivan. 2008. Net antropogenic phosphorus inputs: Spatial and temporal variability in the Chesapeake Bay region. Biogeochemistry 88(3):285-304.

Schipper, L.A., W.D. Robertson, A.J. Gold, D.B. Jaynes, and S.C. Cameron. 2010. Denitrifying bioreactors - An approach for reducing nitrate loads to receiving waters. Ecological Engineering 36(11):1532-1543.

Simon, A., and L. Klimetz. 2008. Relative magnitudes and sources of sediment in benchmark watersheds of the Conservation Effects Assessment Project. Journal of Soil and Water Conservation 63(6):504-522, doi:10.2489/ jswc.63.6.504.

Smiley, Jr., P.C., R.B. Gillespie, K.W. King, and C. Huang. 2009. Management implications of the relationships between water chemistry and fishes within channelized headwater streams in the Midwestern United States. Ecohydrology 2:294-302

Smiley, Jr., P.C., K.W. King, and N.R. Fausey. 2011. Influence of herbaceous riparian buffers on physical habitat, water chemistry, and stream communities within channelized agricultural headwater streams. Ecological Engineering 37:1314-1323.

Smiley, P.C. Jr., K.W. King, R.B. Gillespie, and N.R. Fausey. 2012. Influence of watershed scale atrazine reduction practices on pesticides and fishes within channelized agricultural headwater streams. Journal of Sustainable Watershed Science and Management 1(2):61-75.

Smith, D.R., S.J. Livingston, B.W. Zuercher, M. Larose, G.C. Heathman, and C. Huang. 2008. Nutrient losses from row crop agriculture in Indiana. Journal of Soil 
and Water Conservation 63(6):396-409, doi:10.2489/ jswc.63.6.396.

Smith, D.R., E.A. Warnemuende, B.E. Haggard, and C. Huang. 2006. Dredging of drainage ditches increases short-term transport of soluble phosphorus. Journal of Environmental Quality 35:611-616.

Steiner, J.L., E.J. Sadler, J.-S. Chen, G. Wilson, D. Jmaes, B. Vandenberg, J. Ross, T. Oster, and K. Cole. 2008. Sustaining the Earth's Watersheds-Agricultural Research Data System: Overview of development and challenges. Journal of Soil and Water Conservation 63(6):569-576, doi:10.2489/jswc.63.6.569.

Todd, M.J., G. Vellidis, R.R. Lowrance, and C.M. Pringle. 2009. High sediment oxygen demand within an instream swamp in southern Georgia: implications for low dissolved oxygen levels in coastal blackwater streams. Journal of the American Water Resources Association 45(6):1493-1507.

Tomer, M.D., P.C. Beeson, D.W. Meek, D.N. Moriasi, C.G. Rossi, and A.M. Sadeghi. 2013a. Evaluating simulations of daily discharge from large watersheds using autoregression and an index of flashiness. Transactions American Society of Agricultural Biological Engineers 56(4):1317-1326.

Tomer, M.D., and M.A. Locke. 2011. The challenge of documenting water quality benefits of conservation practices: A review of USDA-ARS's conservation effects assessment project watershed studies. Water Science \& Technology 64(1):300-310.

Tomer, M.D., C.G. Wilson, T.B. Moorman, K.J. Cole, D. Heer, and T.M. Isenhart. 2010. Source-pathway separation of multiple contaminants during a rainfall runoff event in an artificially drained agricultural watershed. Journal of Environmental Quality 39(3):882-895.

Tomer, M.D., W.G. Crumpton, R.L. Bingner, J.A. Kostel, and D.E. James. 2013b. Estimating nitrate load reductions from placing constructed wetlands in a HUC-12 watershed using LiDAR data. Ecological Engineering 56:69-78.

Turner, R.E., N.N. Rabalais, and D. Justic. 2008. Gulf of Mexico hypoxia: Alternate states and a legacy. Environmental Science and Technology 42(7): 2323-2327.

USDA. 2010. Assessment of the Effects of Conservation Practices on Cultivated Cropland in the Upper Mississippi River Basin. Washington, DC: US Department of Agriculture, Natural Resources Conservation Service. http://www.nrcs.usda.gov/ Internet/FSE_DOCUMENTS/stelprdb1042093.pdf.

USDA ARS (Agricultural Research Service). 2012. STEWARDS: Sustaining the earth's watershedsagricultural research data system. http://www.ars.usda. gov/Research/docs.htm?docid=18622.

Veith, T.L., M.W. Van Liew, D.D. Bosch, and J.G. Arnold. 2010. Parameter sensitivity and uncertainty in SWAT: A comparison across 5 USDA-ARS watersheds.
Transactions American Society of Agricultural Biological Engineers 53(5):1477-86.

Veith, T.L., M.L. Wolfe, and C.D. Heatwole. 2004. Cost-effective BMP placement: Optimization versus targeting. Transactions American Society of Agricultural Engineers 47(5):1585-1594.

Verbree, D.A., S.W. Duiker, and P.J.A. Kleinman. 2010. Runoff losses of sediment and phosphorus from no-till and cultivated soils receiving dairy manure. Journal of Environmental Quality 39:1762-1770.

Watts, D.B. and H.A. Torbert. 2009. Impact of gypsum applied to grass buffer strips on reducing soluble $\mathrm{P}$ in surface water runoff. Journal of Environmental Quality 38(4):1511-1517.

White Jr., P.M., T.L. Potter, D.D. Bosch, H. Joo, B. Schaffer, and R. Muñoz-Carpena. 2009. Reduction in metolachlor and degradates concentrations in shallow groundwater through cover crop use. Journal of Agricultural and Food Chemistry 57(20): 9658-9667.

Williams, C.O., R. Lowrance, D.D. Bosch, J.R. Williams, E. Benham, A. Dieppa, R. Hubbard, E. Mas, T. Potter, D. Sotomayor, E.M. Stenglich, T. Strickland, and R.G. Williams. 2013. Hydrology and water quality of a field and riparian buffer adjacent to a mangrove wetland in Jobos Bay watershed, Puerto Rico. Ecological Engineering 56:60-68.

Williams, J.R., R.C. Izaurralde, and E.M. Steglich. 2008. Agricultural Policy/Environmental eXtender Model: Theoretical documentation. Version 0604. BREC Report \#2008-17. Temple, TX: Texas AgriLIFE Research, Texas A\&M University, Blackland Research and Extension Center.

R.A., Kuhnle, C.G. Wilson, S.M. Dabney, R.N. Lerch, C-H. Huang. 2014. Fine sediment sources on Conservation Effects Assessment Project watersheds. Journal of Soil and Water Conservation 69(5):402-413.

Wilson, C.G., R.A. Kuhnle, D.D. Bosch, J.L. Steiner, P.J. Starks, M.D. Tomer, and G.V. Wilson. 2008. Quantifying relative contributions from sediment sources in Conservation Effects Assessment Project watersheds. Journal of Soil and Water Conservation 63(6):523-532, doi:10.2489/jswc.63.6.523.

Yan, B., M.D. Tomer, and D.E. James. 2010. Historical channel movement and sediment accretion along the South Fork of the Iowa River. Journal of Soil and Water Conservation 65(1):1-8, doi:10.2489/jswc.65.1.1 